doi: 10.31140/j.vestnikib.2016.4(198).2

\title{
ИЗУЧЕНИЕ ЭЛЕМЕНТНОГО СОСТАВА ГУМИНОВЫХ И ФУЛЬВОКИСЛОТ ПОЧВ ТАЕЖНЫХ И ТУНДРОВЫХ ЛАНДШАФТОВ
}

\author{
Е.Д. Лодыгин, В.А. Безносиков, Р.С. Василевич \\ Федеральное государственное бюджетное учреждение науки \\ Институт биологии Коми научного центра Уральского отделения РАН, Сыктывкар \\ E-mail: soil99@mail.ru
}

\begin{abstract}
Аннотация. Проведено систематическое изучение элементного состава препаратов гуминовых (ГК) и фульвокислот (ФК) почв разных климатических зон Республики Коми. ГК почв таежной зоны в большей степени обогащены азотом, а ФК - кислородом по сравнению с тундровыми почвами. Структура ГК и ФК тундровых почв характеризуется наличием развитой алифатической части макромолекул и низкой степенью ароматичности.
\end{abstract}

Ключевые слова: почва, гуминовые и фульвокислоты, элементный состав, тайга, тундра

\section{Введение}

Элементный состав гумусовых веществ (ГВ)одна из важнейших характеристик, которая используется в качестве показателя уровня гумификации, окисленности ГК и ФК и для косвенной оценки степени их конденсированности. ГК и ФК являются группами высокомолекулярных соединений, характеризующихся нестехиометричностью состава, нерегулярностью строения, гетерогенностью структурных элементов и полидисперсностью макромолекул.

ГК и ФК являются неотъемлемой частью гумуса, участвующего в обеспечении устойчивости экосистем через реализацию их различных экологических функций. Они играют существенную роль в круговороте веществ и потоке энергии, влияют на рост и развитие живых организмов, связанных с почвой, выступают как регулятор почвенных процессов. ГК и ФК, в том числе и их элементный состав, во времени (Дергачева, 2011; Трансформация..., 2012; Элементный..., 2012) отражают в структуре и свойствах особенности биоклиматической обстановки, в которой они формируются (Абакумов, 2009; Завьялова, 2011; Мотузова, 2012).

Д.С. Орлов (1974) показал, что распределение углерода в ГК и ФК одного типа почв апроксимируется законом нормального распределения, причем коэффициенты варьирования зависят от типа почвы. Им были установлены средние значения содержания углерода в гумусовых кислотах главных типов почв. Эти данные позволили сделать вывод, что ГК и ФК - не случайная смесь органических соединений, и их состав зависит от условий почвообразования. Однако, помимо углерода, водорода, кислорода, азота и серы в состав всех выделенных препаратов гумусовых кислот входит и неорганическая часть, состоящая из зольных элементов (преимущественно ионов металлов, оксидов кремния и алюминия).

Для познания свойств ГВ, обеспечивающих выполнение ими экосистемных функций, требуется расширение знаний об элементном составе этих компонентов гумуса современных почв раз- личных природных зон и почвенных провинций в разнообразных экологических условиях (Некрасова, 2013; Максимова, 2014).

Цель работы - выявить закономерности элементного состава гуминовых и фульвокислот в естественных почвах таежной и тундровой зон европейского северо-востока России.

\section{Объекты и методы}

Объектами исследований послужили почвы южной тайги: дерново-подзолистые (Umbric Albeluvisols) (World reference base..., 2006); средней тайги: типичные подзолистые (Haplic Albeluvisols) и торфянисто-подзолисто-глееватые (Stagnic Histic Albeluvisols); северной тайги: глееподзолистые (Stagnic Albeluvisols), торфянисто-подзолистоглееватые; южной тундры: тундровые поверхностно-глеевые (Stagnic Cambisols), торфянисто-тундровые глеевые (Histic Gleysols) и торфяно-тундровые глеевые (Histic Cryosols). Материал собран на территории Республики Коми (рис. 1). При отборе почвенных образцов был использован маршрутный метод, позволяющий учитывать закономерности формирования почвенного покрова в ландшафтах: от водораздела (автоморфные почвы) до геохимически подчиненных ландшафтов - понижений (гидроморфные почвы) в соответствии с ГОСТ 17.4.3.01-83 (2008) и ГОСТ 17.4.4.02-84 (2008). Характеристика климата районов исследования приведена в табл. 1 (Атлас по климату..., 1997).

Исследования в подзоне южной тайги проводили на Летском стационаре отдела почвоведения Института биологии Коми НЦ УрО РАН. Согласно почвенно-географическому районированию, данная территория относится к Летскому округу дерново-подзолистых почв Среднерусской провинции (Атлас почв..., 2010). Разрез дерновоподзолистой почвы расположен в 1 км к северозападу от дер. Крутотыла Прилузского р-на на пологом склоне увала западной экспозиции в березово-осиново-еловом лесу. Координаты разреза: $59^{\circ} 38^{\prime} 0.0^{\prime \prime}$ с.ш., 49 21'36.5" в.д. Абсолютная высота над уровнем моря около 180 м. Уклоны 
не превышают 0.02. Колебания отметок нано- и микрорельефа на плакоре не превышают 23 см, на склоне - $20 \mathrm{cm,} \mathrm{размеры} \mathrm{и} \mathrm{глуби-}$ ны их незначительно увеличиваются в ложбине за счет пристволовых бугорков и ветровальных нарушений. В травяно-кустарничковом покрове обычны черника миртолистная (Vaccinium myrtillus L.), костяника каменистая (Rubus saxa tilis L.), грушанка (Pyrola L.), кислица обыкновенная (Oxalis acetosella L.). Напочвенный покров из зеленых мхов развит слабо.

Исследования почв, широко распространенных в подзоне средней тайги, проведены на Максимовском стационаре отдела почвоведения Института биологии. Согласно почвенно-географическому районированию, данная территория относится к Сысольскому округу типичных подзолистых и торфянисто-подзолисто-глееватых почв Сысола-Вычегодской провинции (Путеводитель..., 2002). Разрез типичной подзолистой почвы заложен в 8 км к западу от Сыктывкара на вершине водораздельного холма, абсолютная высота над уровнем моря составляет 170 м, на гребне микроповышения высотой около 1.5 м. Координаты разреза: $61^{\circ} 39^{\prime}$ $44.6^{\prime \prime}$ с.ш., 50 41'10.4" в.д. Березово-еловый лес чернично-зеленомошный. Разрез торфянисто-подзолисто-глееватой почвы заложен в 74 м от разреза типичной подзолистой почвы. Координаты разреза: $61^{\circ} 39^{\prime} 42.4^{\prime \prime}$ с.ш., 50 41'08.4" в.д. Абсолютная высота над уровнем моря около 160 м. Березово-еловый долгомошно-сфагновый лес. Вблизи разреза - сфагновый покров.

Исследования почв в подзоне северной тайги проведены в 3 км к западу от пос. Троицко-Печорск. Согласно почвенно-географическому районированию, данная территория относится к Ижма-Печорскому округу подзолов иллювиально-гумусово-эжелезистых, торфянисто- и торфяно-подзолисто-глеевых иллювиально-гумусовых, глееподзолистых и болотно-подзолистых потв Тимано-Петорской провинции (Атлас почв..., 2010). Изученный ряд почв располагается на плоской вершине водораздельного увала.

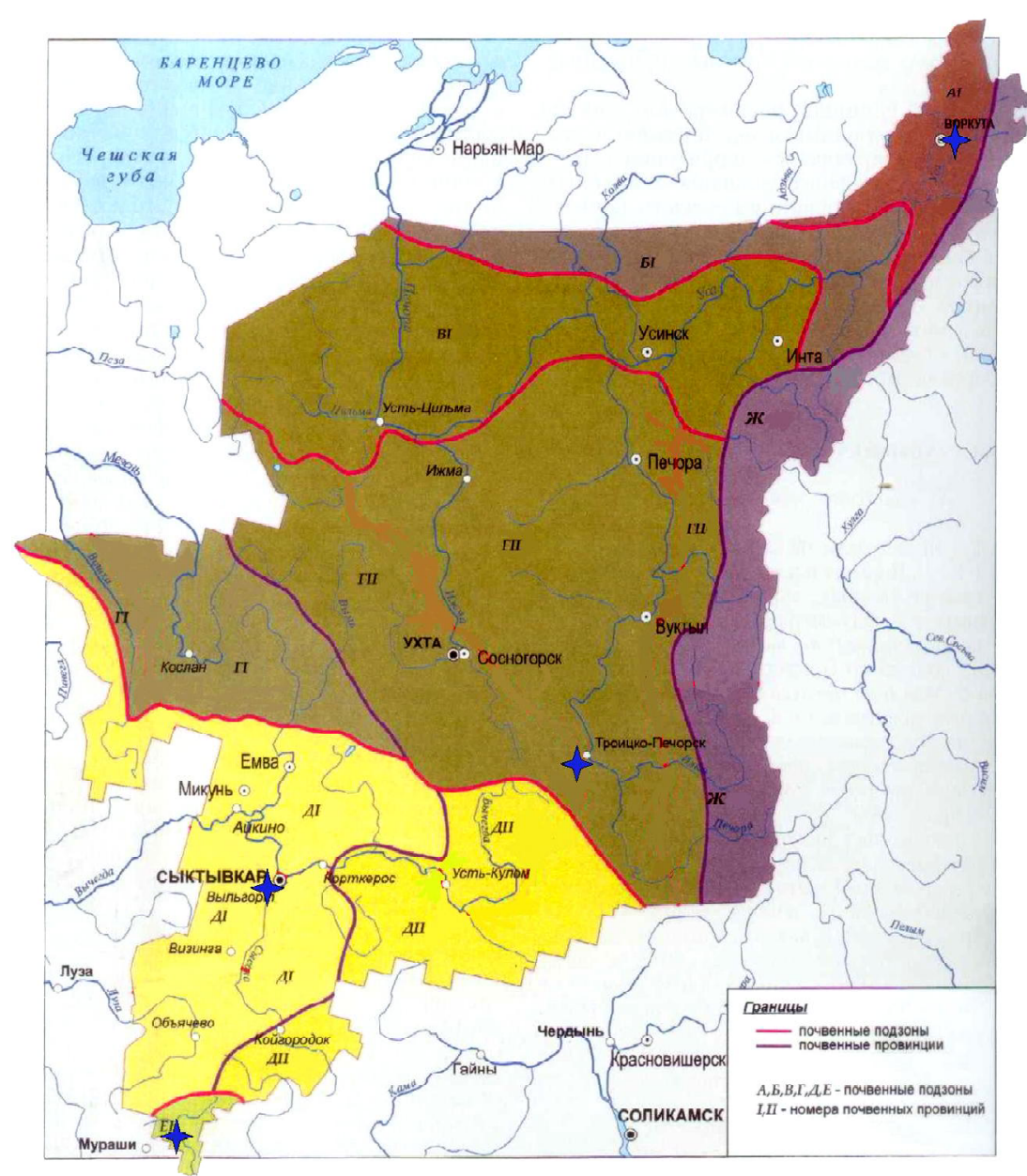

Рис. 1. Места расположения точек пробоотбора $(\nmid)$ : A - подзона южной тундры: Al - Большеземельская провинция. Б - подзона лесотундры: БІ - Канино-Печорская провинция. В - подзона крайнесеверной тайги: ВI- Печора-Усинская провинция. Г - подзона северной тайги: ГІ - Мезень-Тиманская провинция, ГІІ - Тимано-Печорская провинция. Д - подзона средней тайги: ДІ - Сысола-Вычегодская провинция, ДІІ - Вычегодская провинция. E - подзона южной тайги: EI - Среднерусская провинция. Ж - Уральская горная провинция.

Таблица 1

Климатические условия районов исследования

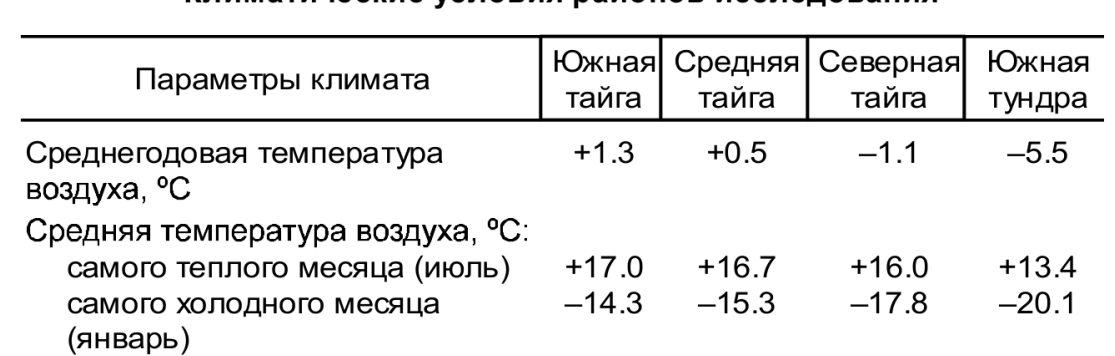

Продолжительность периода

со среднесуточной температурой, дней:

выше $0^{\circ} \mathrm{C}$

выше $5^{\circ} \mathrm{C}$

выше $10^{\circ} \mathrm{C}$

Глубина промерзания почвы, см

Мощность снежного покрова, см

Годовая сумма осадков, мм в том числе в летний период, MM

$\begin{array}{cccc}202 & 190 & 175 & 125 \\ 151 & 140 & 135 & 90 \\ 110 & 100 & 92 & 43 \\ 43 & 89 & 101 & 139 \\ 61 & 60 & 64 & 74 \\ 622 & 560 & 590 & 548 \\ 218 & 195 & 201 & 172\end{array}$


Глееподзолистые почвы, формирующиеся под еловыми зеленомошными лесами, занимают периферическую часть вершины. Под еловыми долгомошными и сфагново-долгомошными лесами ближе к центру увала развиваются торфянистоподзолисто-глееватые почвы. Разрез глееподзолистой почвы заложен на вершине плоского межручейного увала. Координаты разреза: $62^{\circ} 41^{\prime} 21.0^{\prime \prime}$ с.ш., 56 08'59.1" в.д. Абсолютная высота над уровнем моря около 140 м. Ельник чернично-зеленомошный, в травяно-кустарничковом покрове доминирует черника, в напочвенном покрове - зеленые мхи. Разрез торфянисто-подзолисто-глееватой почвы расположен в 60 м от участка с глееподзолистой почвой на пологом слабо дренированном привершинном склоне увала. Координа-

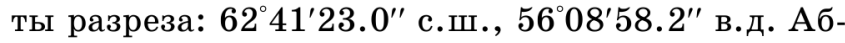
солютная высота над уровнем моря около 110 м. Ельник сфагново-долгомошный, в травяно-кустарничковом ярусе доминируют брусника ( $\mathrm{Vacci}$ nium vitis-idaea L.), хвощ (Equisetum L.), осока шаровидная (Carex globularis), морошка (Rubus chamaemorus L.), в напочвенном покрове присутствуют в небольшом количестве гипновые мхи.

Исследования тундровых почв проведены в Ворку'тинском районе Реснублики Коми в Большеземельской тундре на участках с распространением массивно-островной многолетней мерзлоты. Согласно почвенно-географическому районированию, данная территория относится к Воркутинскому округу тундровых поверхностно-глеевых, торфянисто- и торфяно-тундровых глеевых мерзлотных почв Большеземельской провинции (Атлас почв..., 2010). Территория представляет собой полого-увалистую равнину, покрытую чехлом покровных пылеватых суглинков мощностью менее 10 м (Безносиков, 2012). Разрез тундровой поверхностно-глеевой почвы заложен на пологом склоне моренного увала Нерусовей-мусюр. Координаты разреза: $67^{\circ} 31^{\prime} 57.5^{\prime \prime}$ с.ш., $64^{\circ} 07^{\prime} 8.5^{\prime \prime}$ в.д. Абсолютная высота над уровнем моря около 220 м. Ивняково-ерниковая моховая мелкобугорковатая тундра, в растительном покрове преобладают гипновые мхи с примесью политриховых, брусника, редко встречаются осоки (Carex sp.), единично - экземпляры березы карликовой (Betula nana L.). Разрез торфянисто-тундровой глеевой почвы заложен на средней части юго-западного склона, уклон $3^{\circ}$. Координаты разреза: $67^{\circ} 35^{\prime}$ 26.6" с.ш., 6409'54.3" в.д. Абсолютная высота над уровнем моря около 150 м. Мохово-лишайниковый покров, политриховые и сфагновые мхи, лишайники, водяника черная (Empetrum nigrum L.), багульник (Ledum sp.), по бугоркам - морошка, голубика обыкновенная (Vaccinium uliginosum L.). Микрорельеф бугорковатый, бугры высотой до $10 \mathrm{~cm}$, диаметром до 1.5 м. Межбугорковое понижение. Разрез торфяно-тундровой глеевой почвы заложен на средней части юго-западного склона, уклон $3^{\circ}$, в 100 м к югу от разре- за торфянисто-тундровой глеевой почвы. Координаты разреза: $67^{\circ} 35^{\prime} 23.5^{\prime \prime}$ с.ш., $64^{\circ} 09^{\prime} 53.1^{\prime \prime}$ в.д. Абсолютная высота над уровнем моря около 140 м. Разрез заложен на бугорке.

Содержание углерода, азота и водорода в пре-

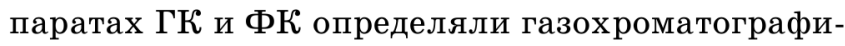
чески на элементном анализаторе EA-1110 (Carlo Erba, Италия) в соответствии с аттестованными методиками количественного химического анализа (Методика выполнения..., 2009; Кондратенок, 2011) в ЦКП «Хроматография» Института биологии Коми НЦ УрО РАН. Зольность препаратов ГК определяли по ГОСТ 11306-83 (1995), кислород - по разнице между $100 \%$ и суммой массовой (мольной) долями углерода, азота и водорода. Статистическую обработку данных проводили с использованием прикладных программ Microsoft Excel.

\section{Результаты и обсуждение}

Данные элементного состава гуминовых кислот изученных почв показывают (табл. 2 и 3), что для них характерна высокая обуглероженность по сравнению с фульвокислотами. В ГК мольная доля $(x)$ углерода составляет $32.2-42.9 \%$,

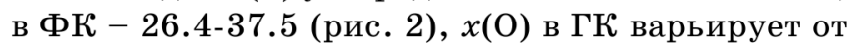
12.5 до $22.0 \%, \Phi К-24-42 \%$.

По содержанию углерода препараты ГК и ФК можно разделить на две группы: 1) с пониженной $x$ (C) до $37 \%$ для ГК и до $31 \%$ - для ФК;

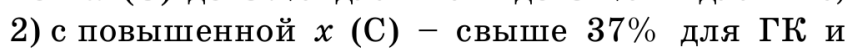
свыше $31 \%$ - для ФК. В первую группу входят, как правило, ГК элювиальных горизонтов, во вторую - органогенных и иллювиальных. Изменение элементного состава препаратов $\Phi К$ по профилю обусловлено вымыванием их низкоуглеродистых молекул из органогенных горизонтов.

Изменение мольной доли кислорода в ГК по профилю не имеет ярко выраженной закономерности. Для ФК установлено увеличение содержания кислорода по профилю как таежных, так и тундровых почв, что обусловлено лучшей растворимостью кислородобогащенных гидрофильных молекул ФК и их миграцией в нижележащие минеральные горизонты.

Содержание азота в гуминовых кислотах в среднем в два раза выше, чем в фульвокислотах, что подтверждают результаты химического анализа и атомное отношение $\mathrm{C} / \mathrm{N}$ : для $\Gamma К-8.6$ 31.2, ФК - 13.3-64.3. В профильном распределении азота в препаратах $Г К$ и ФК отмечается тенденция к его снижению. Гуминовые и фульвокислоты дерново-подзолистых почв в большей степени обогащены азотом по сравнению с другими исследованными почвами.

Для изображения состава трехкомпонентных систем Дж. Гиббсом был предложен равносторонний треугольник, на который нанесена координатная сетка в виде линий, параллельных сторонам треугольника (рис. 2). Вершина треугольни- 
Распределение и элементный состав гуминовых кислот почв

\begin{tabular}{|c|c|c|c|c|c|c|c|c|c|c|}
\hline \multirow{2}{*}{ Горизонт } & \multirow{2}{*}{$\begin{array}{c}\text { Глубина, } \\
\text { см }\end{array}$} & \multicolumn{4}{|c|}{ Содержание, \% } & \multicolumn{3}{|c|}{$\begin{array}{c}\text { Атомные } \\
\text { отношения }\end{array}$} & \multirow{2}{*}{$(\mathrm{H} / \mathrm{C})_{\text {исп }}{ }^{*}$} & \multirow{2}{*}{$\begin{array}{c}\text { Степень } \\
\text { окисленности } \\
(\omega)\end{array}$} \\
\hline & & C & $\mathrm{H}$ & 0 & $\mathrm{~N}$ & $\mathrm{H} / \mathrm{C}$ & $\mathrm{O} / \mathrm{C}$ & $\mathrm{C} / \mathrm{N}$ & & \\
\hline
\end{tabular}

\section{Южная тайга}

\begin{tabular}{|c|c|c|c|c|c|c|c|c|c|c|}
\hline \multirow[b]{2}{*}{ АОАдер. } & \multicolumn{10}{|c|}{ Дерново-подзолистая почва } \\
\hline & $0-4$ & $\frac{53.5 \pm 1.7}{38.3 \pm 1.2}$ & $\frac{4.5 \pm 0.4}{39 \pm 4}$ & $\frac{38 \pm 4}{20.2 \pm 2.4}$ & $\frac{4.37 \pm 0.29}{2.68 \pm 0.18}$ & 1.01 & 0.53 & 14.3 & $1.72 \pm 0.05$ & +0.04 \\
\hline $\mathrm{A} 2^{\prime}$ & $4-15$ & $\frac{54.1 \pm 1.7}{39.0 \pm 1.2}$ & $\frac{4.4 \pm 0.4}{38 \pm 4}$ & $\frac{36 \pm 4}{19.4 \pm 2.3}$ & $\frac{5.7 \pm 0.4}{3.53 \pm 0.24}$ & 0.97 & 0.50 & 11.0 & $1.64 \pm 0.05$ & +0.02 \\
\hline A2" & $15-28$ & $\frac{56.1 \pm 1.8}{39.3 \pm 1.3}$ & $\frac{4.7 \pm 0.4}{40 \pm 4}$ & $\frac{33 \pm 4}{17.2 \pm 2.0}$ & $\frac{6.4 \pm 0.4}{3.83 \pm 0.26}$ & 1.01 & 0.44 & 10.3 & $1.60 \pm 0.05$ & -0.14 \\
\hline A2B & $28-43$ & $\frac{48.9 \pm 1.6}{35.8 \pm 1.1}$ & $\frac{4.3 \pm 0.4}{38 \pm 4}$ & $\frac{40 \pm 5}{22.0 \pm 2.6}$ & $\frac{6.6 \pm 0.4}{4.15 \pm 0.28}$ & 1.06 & 0.61 & 8.6 & $1.88 \pm 0.06$ & +0.17 \\
\hline \multicolumn{11}{|c|}{$\begin{array}{c}\text { Средняя тайга } \\
\text { Типичная подзолистая почва }\end{array}$} \\
\hline $\mathrm{AO}$ & $0-5$ & $\frac{54.5 \pm 1.7}{35.6 \pm 1.1}$ & $\frac{5.7 \pm 0.5}{45 \pm 4}$ & $\frac{36 \pm 4}{17.8 \pm 2.1}$ & $\frac{3.45 \pm 0.23}{1.96 \pm 0.13}$ & 1.25 & 0.50 & 18.4 & $1.92 \pm 0.06$ & -0.25 \\
\hline $\mathrm{A} 1 \mathrm{~A} 2 \mathrm{~h}$ & $5-7$ & $\frac{53,8 \pm 1.7}{35.2 \pm 1.1}$ & $\frac{5.7 \pm 0.5}{45 \pm 4}$ & $\frac{37 \pm 4}{18.0 \pm 2.1}$ & $\frac{3.78 \pm 0.25}{2.12 \pm 0.14}$ & 1.27 & 0.51 & 16.6 & $1.96 \pm 0.06$ & -0.25 \\
\hline$A 2^{\prime}$ & $7-10$ & $\frac{52.9 \pm 1.7}{36.5 \pm 1.2}$ & $\frac{5.0 \pm 0.5}{42 \pm 4}$ & $\frac{39 \pm 5}{20.3 \pm 2.4}$ & $\frac{2.79 \pm 0.19}{1.65 \pm 0.11}$ & 1.14 & 0.56 & 22.1 & $1.89 \pm 0.06$ & -0.02 \\
\hline A2" & $18-35$ & $\frac{53.7 \pm 1.7}{36.3 \pm 1.2}$ & $\frac{5.3 \pm 0.5}{43 \pm 4}$ & $\frac{39 \pm 8}{20 \pm 4}$ & $\frac{2.0 \pm 0.4}{1.16 \pm 0.21}$ & 1.18 & 0.54 & 31.2 & $1.91 \pm 0.06$ & -0.09 \\
\hline \multicolumn{11}{|c|}{ Торфянисто-подзолисто-глееватая почва } \\
\hline O1 & $0-8$ & $\frac{52.6 \pm 1.7}{34.5 \pm 1.1}$ & $\frac{5.7 \pm 0.5}{45 \pm 4}$ & $\frac{38 \pm 5}{18.9 \pm 2.3}$ & $\frac{3.24 \pm 0.22}{1.82 \pm 0.12}$ & 1.30 & 0.55 & 18.9 & $2.03 \pm 0.06$ & -0.20 \\
\hline A2hg & $12-20$ & $\frac{58.8 \pm 1.9}{32.2 \pm 1.0}$ & $\frac{8.2 \pm 0.8}{54 \pm 5}$ & $\frac{30 \pm 4}{12.5 \pm 1.5}$ & $\frac{2.62 \pm 0.18}{1.23 \pm 0.08}$ & 1.68 & 0.39 & 26.2 & $2.20 \pm 0.07$ & -0.91 \\
\hline$A 2 g^{\prime}$ & $20-28$ & $\frac{56.8 \pm 1.8}{33.0 \pm 1.1}$ & $\frac{7.3 \pm 0.7}{51 \pm 5}$ & $\frac{33 \pm 4}{14.3 \pm 1.7}$ & $\frac{3.20 \pm 0.21}{1.60 \pm 0.11}$ & 1.55 & 0.43 & 20.7 & $2.12 \pm 0.06$ & -0.68 \\
\hline A2g" & $28-37$ & $\frac{55.1 \pm 1.8}{35.2 \pm 1.1}$ & $\frac{6.0 \pm 0.6}{46 \pm 4}$ & $\frac{36 \pm 4}{17.0 \pm 2.0}$ & $\frac{3.36 \pm 0.23}{1.84 \pm 0.12}$ & 1.31 & 0.48 & 19.1 & $1.96 \pm 0.06$ & -0.34 \\
\hline \multicolumn{11}{|c|}{$\begin{array}{l}\text { Северная тайга } \\
\text { Глееподзолистая почва }\end{array}$} \\
\hline A0 & $0-5$ & $\frac{58.0 \pm 1.9}{38.5 \pm 1.2}$ & $\frac{5.4 \pm 0.5}{43 \pm 4}$ & $\frac{33 \pm 4}{16.2 \pm 1.9}$ & $\frac{3.97 \pm 0.27}{1.26 \pm 0.15}$ & 1.12 & 0.42 & 17.1 & $1.68 \pm 0.05$ & -0.27 \\
\hline A2 $g^{\prime}$ & $5-10$ & $\frac{59.5 \pm 1.9}{37.5 \pm 1.2}$ & $\frac{6.1 \pm 0.6}{46 \pm 4}$ & $\frac{30 \pm 4}{14.0 \pm 1.7}$ & $\frac{4.8 \pm 0.3}{2.58 \pm 0.17}$ & 1.23 & 0.37 & 14.5 & $1.73 \pm 0.05$ & -0.48 \\
\hline A2g" & $10-16$ & $\frac{54.2 \pm 1.7}{35.6 \pm 1.1}$ & $\frac{5.6 \pm 0.5}{44 \pm 4}$ & $\frac{34 \pm 4}{16.8 \pm 2.0}$ & $\frac{6.0 \pm 0.4}{3.40 \pm 0.23}$ & 1.25 & 0.47 & 10.5 & $1.88 \pm 0.06$ & -0.30 \\
\hline A2B & $16-35$ & $\frac{54.1 \pm 1.7}{37.7 \pm 1.2}$ & $\frac{4.8 \pm 0.5}{41 \pm 4}$ & $\frac{37 \pm 4}{19.5 \pm 2.3}$ & $\frac{3.73 \pm 0.25}{2.23 \pm 0.15}$ & 1.07 & 0.52 & 16.9 & $1.77 \pm 0.05$ & -0.04 \\
\hline \multicolumn{11}{|c|}{ Торфянисто-подзолисто-глееватая почва } \\
\hline O1 & $0-10$ & $\frac{57.2 \pm 1.8}{38.4 \pm 1.2}$ & $\frac{5.3 \pm 0.5}{43 \pm 4}$ & $\frac{34 \pm 4}{17.1 \pm 2.0}$ & $\frac{3.47 \pm 0.23}{1.99 \pm 0.13}$ & 1.11 & 0.45 & 19.2 & $1.71 \pm 0.05$ & -0.22 \\
\hline $\mathrm{O} 2$ & $10-12$ & $\frac{51.6 \pm 1.7}{35.9 \pm 1.1}$ & $\frac{5.0 \pm 0.5}{41 \pm 4}$ & $\frac{41 \pm 8}{21 \pm 4}$ & $\frac{2.6 \pm 0.5}{1.53 \pm 0.28}$ & 1.15 & 0.59 & 23.4 & $1.95 \pm 0.06$ & -0.04 \\
\hline A2hg & $12-15$ & $\frac{49.7 \pm 1.6}{32.9 \pm 1.1}$ & $\frac{5.6 \pm 0.5}{45 \pm 4}$ & $\frac{42 \pm 5}{20.7 \pm 2.5}$ & $\frac{3.02 \pm 0.20}{1.72 \pm 0.11}$ & 1.36 & 0.63 & 19.2 & $2.20 \pm 0.07$ & -0.10 \\
\hline $\mathrm{A} 2 \mathrm{~g}$ & $15-20$ & $\frac{53.0 \pm 1.7}{36.1 \pm 1.2}$ & $\frac{5.2 \pm 0.5}{42 \pm 4}$ & $\frac{39 \pm 5}{19.8 \pm 2.4}$ & $\frac{3.04 \pm 0.20}{1.77 \pm 0.12}$ & 1.17 & 0.55 & 20.4 & $1.91 \pm 0.06$ & -0.07 \\
\hline $\mathrm{A} 2 \mathrm{Bg}$ & $20-25$ & $\frac{54.7 \pm 1.7}{36.8 \pm 1.2}$ & $\frac{5.3 \pm 0.5}{43 \pm 4}$ & $\frac{37 \pm 8}{19 \pm 4}$ & $\frac{2.6 \pm 0.5}{1.49 \pm 0.27}$ & 1.16 & 0.51 & 24.8 & $1.85 \pm 0.06$ & -0.13 \\
\hline $\mathrm{A} 2 \mathrm{Bg}$ & $35-40$ & $\frac{61.2 \pm 2.0}{42.9 \pm 1.4}$ & $\frac{4.6 \pm 0.4}{39 \pm 4}$ & $\frac{31 \pm 4}{16.1 \pm 1.9}$ & $\frac{3.61 \pm 0.24}{2.17 \pm 0.15}$ & 0.91 & 0.38 & 19.8 & $1.41 \pm 0.04$ & -0.15 \\
\hline \multicolumn{11}{|c|}{ Южная тундра } \\
\hline
\end{tabular}

Тундровая поверхностно-глеевая почва

\begin{tabular}{|c|c|c|c|c|c|c|c|c|c|c|}
\hline AO & $0-5$ & $\frac{53.2 \pm 1.7}{36.8 \pm 1.2}$ & $\frac{5.0 \pm 0.5}{41 \pm 4}$ & $\frac{38 \pm 5}{19.5 \pm 2.3}$ & $\frac{4.23 \pm 0.28}{2.51 \pm 0.17}$ & 1.12 & 0.53 & 14.7 & $1.83 \pm 0.05$ & -0.06 \\
\hline $\mathrm{AOAh}$ & $5-10$ & $\frac{58.1 \pm 1.9}{37.6 \pm 1.2}$ & $\frac{5.7 \pm 0.5}{45 \pm 4}$ & $\frac{31 \pm 4}{14.9 \pm 1.8}$ & $\frac{5.4 \pm 0.4}{2.98 \pm 0.20}$ & 1.18 & 0.40 & 12.6 & $1.72 \pm 0.05$ & -0.39 \\
\hline
\end{tabular}


Окончание табл. 2

\begin{tabular}{|c|c|c|c|c|c|c|c|c|c|c|}
\hline \multirow[t]{2}{*}{ Горизонт } & \multirow{2}{*}{$\begin{array}{c}\text { Глубина, } \\
\text { см }\end{array}$} & \multicolumn{4}{|c|}{ Содержание, \% } & \multicolumn{3}{|c|}{$\begin{array}{l}\text { Атомные } \\
\text { отношения }\end{array}$} & \multirow{2}{*}{$(\mathrm{H} / \mathrm{C})_{\text {ucr }}{ }^{*}$} & \multirow{2}{*}{$\begin{array}{c}\text { Степень } \\
\text { окисленности } \\
(\omega) \\
\end{array}$} \\
\hline & & $\mathrm{C}$ & $\mathrm{H}$ & $\mathrm{O}$ & $\mathrm{N}$ & $\mathrm{H} / \mathrm{C}$ & $\mathrm{O} / \mathrm{C}$ & $\mathrm{C} / \mathrm{N}$ & & \\
\hline G & $10-28$ & $\frac{58.9 \pm 1.9}{38.0 \pm 1.2}$ & $\frac{5.7 \pm 0.5}{44 \pm 4}$ & $\frac{30 \pm 4}{14.5 \pm 1.7}$ & $\frac{5.4 \pm 0.4}{2.98 \pm 0.20}$ & 1.17 & 0.38 & 12.8 & $1.68 \pm 0.05$ & -0.41 \\
\hline \multicolumn{11}{|c|}{ Торфянисто-тундровая глеевая почва } \\
\hline $\mathrm{O}$ & $0-14$ & $\frac{55.1 \pm 1.8}{37.1 \pm 1.2}$ & $\frac{5.3 \pm 0.5}{43 \pm 4}$ & $\frac{36 \pm 4}{18.1 \pm 2.2}$ & $\frac{3.74 \pm 0.25}{2.16 \pm 0.14}$ & 1.15 & 0.49 & 17.2 & $1.81 \pm 0.05$ & -0.18 \\
\hline G & $17-25$ & $\frac{55.5 \pm 1.8}{37.3 \pm 1.2}$ & $\frac{5.3 \pm 0.5}{43 \pm 4}$ & $\frac{34 \pm 4}{17.2 \pm 2.1}$ & $\frac{5.0 \pm 0.3}{2.88 \pm 0.19}$ & 1.14 & 0.46 & 13.0 & $1.76 \pm 0.05$ & -0.22 \\
\hline \multicolumn{11}{|c|}{ Торфяно-тундровая глеевая почва } \\
\hline $\mathrm{O}$ & $0-26$ & $\frac{54.7 \pm 1.7}{36.1 \pm 1.2}$ & $\frac{5.6 \pm 0.5}{44 \pm 4}$ & $\frac{36 \pm 4}{17.7 \pm 2.1}$ & $\frac{4.04 \pm 0.27}{2.28 \pm 0.15}$ & 1.22 & 0.49 & 15.8 & $1.88 \pm 0.06$ & -0.24 \\
\hline Gf & $28-40$ & $\frac{56.1 \pm 1.8}{36.1 \pm 1.2}$ & $\frac{5.8 \pm 0.5}{45 \pm 4}$ & $\frac{33 \pm 4}{16.1 \pm 1.9}$ & $\frac{4.6 \pm 0.3}{2.55 \pm 0.17}$ & 1.25 & 0.45 & 14.2 & $1.85 \pm 0.06$ & -0.36 \\
\hline
\end{tabular}

Примечание: * $(\mathrm{H} / \mathrm{C})_{n с п}=(\mathrm{H} / \mathrm{C})+2 \times(\mathrm{O} / \mathrm{C}) \times 0.67$ (Орлов, 1985); над чертой - массовая доля, под чертой - мольная доля $(x)$; все расчеты приведены на абсолютно сухие и обеззоленные препараты.

ка $x(\mathrm{C})$ отвечает $100 \%$ мольной доли атомов углерода, линия 9-9 отвечает 90\% и т.д. Аналогично вершина $x(\mathrm{H})$ отвечает $100 \%$ мольной доли атомов водорода, линия $1-1^{\prime}-90 \%$. Поскольку в состав ГК и ФК входят более трех различных атомов, то вершина треугольника $x(\mathrm{O}+\mathrm{N})$ отвечает $100 \%$ мольной доли оставшихся элементов (в основном кислорода и азота), линия 1-9' - 90\% . Любая точка на площади треугольника однозначно определяет состав молекул ГК и ФК. Диаграмма построена с использованием Tri-plot для MS Excel (Graham, 2000).

Обособленное положение ФК на диаграмме позволяет предположить, что механизм их образования из растительных остатков несколько иной, чем для ГК. Графико-статистический анализ и данные табл. 2 демонстрирует более высо- кую окисленность ФК по сравнению с ГК, что указывает на развитие $\mathrm{O}, \mathrm{N}$-замещенных алифатических фрагментов.

Анализ элементного состава препаратов гуминовых кислот показал, что ГК дерново-подзолистой почвы наиболее гумифицированы - об этом свидетельствуют их низкие значения атомных соотношений $(\mathrm{H} / \mathrm{C})_{\text {исп }}$ и высокие величины $\mathrm{O} / \mathrm{C}, \mathrm{C}_{\text {гк }} /$ $\mathrm{C}_{\text {фк }}$. Для ГК из почв средней и северной тайги при переходе от органогенных горизонтов к минеральным, начала характерно увеличение значения $(\mathrm{H} / \mathrm{C})_{\text {исп }}$, что обусловлено поступлением в эти горизонты миграционноспособных ГК с высоким содержанием кислородсодержащих функциональных групп. При рассмотрении элементного состава ГК из более глубоких горизонтов наблюдается их дальнейшая гумификация, со-

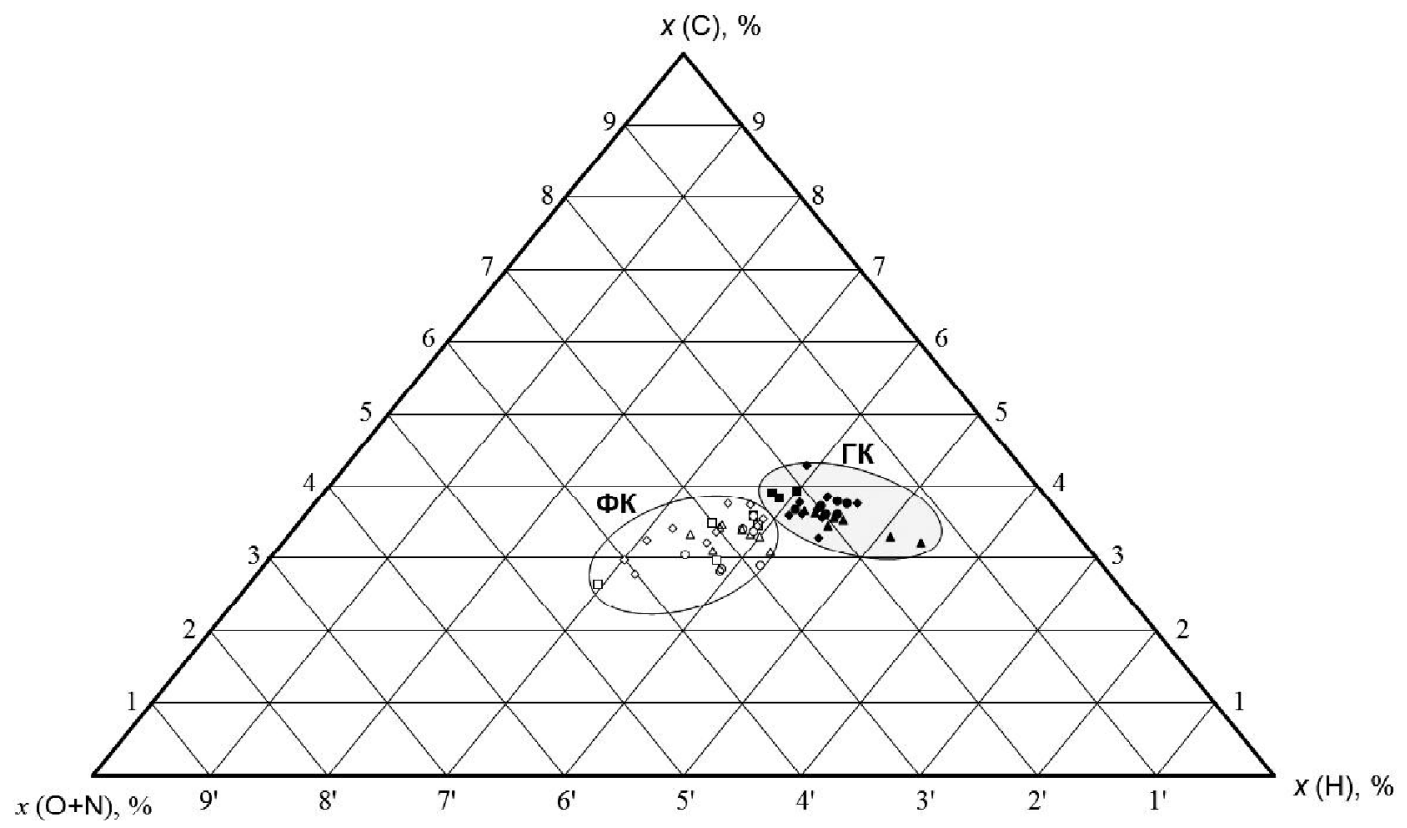

Рис. 2. Диаграмма элементного состава гуминовых и фульвокислот почв южной (ГКच, ФКБ), средней (ГКА, ФК $\triangle$ ),

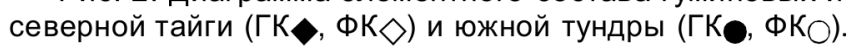


Распределение и элементный состав фульвокислот почв

\begin{tabular}{|c|c|c|c|c|c|c|c|c|c|c|}
\hline \multirow[t]{2}{*}{ Горизонт } & \multirow{2}{*}{$\begin{array}{c}\text { Глубина, } \\
\text { см }\end{array}$} & \multicolumn{4}{|c|}{ Содержание, \% } & \multicolumn{3}{|c|}{$\begin{array}{c}\text { Атомные } \\
\text { отношения }\end{array}$} & \multirow[t]{2}{*}{$(\mathrm{H} / \mathrm{C})_{\text {ucn }}$} & \multirow{2}{*}{$\begin{array}{c}\text { Степень } \\
\text { окисленности } \\
(\omega)\end{array}$} \\
\hline & & $\mathrm{C}$ & $\mathrm{H}$ & $\mathrm{O}$ & $\mathrm{N}$ & $\mathrm{H} / \mathrm{C}$ & $\mathrm{O} / \mathrm{C}$ & $\mathrm{C} / \mathrm{N}$ & & \\
\hline
\end{tabular}

\section{Южная тайга}

Дерново-подзолистая почва

\begin{tabular}{|c|c|c|c|c|c|c|c|c|c|c|}
\hline \multirow[b]{2}{*}{ АОАдер. } & & & & & & & & & & \\
\hline & $0-4$ & $\frac{47.8 \pm 1.5}{34.6 \pm 1.1}$ & $\frac{3.85 \pm 0.26}{39 \pm 4}$ & $\frac{44 \pm 5}{24 \pm 2.8}$ & $\frac{3.85 \pm 0.26}{2.39 \pm 0.16}$ & 1.13 & 0.69 & 14.5 & $2.05 \pm 0.06$ & +0.24 \\
\hline$A 2^{\prime}$ & $4-15$ & $\frac{44.8 \pm 1.4}{34.9 \pm 1.1}$ & $\frac{3.7 \pm 0.3}{35 \pm 3}$ & $\frac{49 \pm 10}{28 \pm 6}$ & $\frac{2.9 \pm 0.5}{1.9 \pm 0.3}$ & 0.99 & 0.81 & 18.1 & $2.08 \pm 0.06$ & +0.63 \\
\hline A2" & $15-28$ & $\frac{30.2 \pm 1.0}{26.4 \pm 0.8}$ & $\frac{2.83 \pm 0.26}{29.6 \pm 2.8}$ & $\frac{65 \pm 13}{42 \pm 9}$ & $\frac{2.1 \pm 0.4}{1.59 \pm 0.29}$ & 1.12 & 1.61 & 16.6 & $3.27 \pm 0.10$ & +2.09 \\
\hline A2B & $28-43$ & $\frac{39.2 \pm 1.3}{29.7 \pm 1.0}$ & $\frac{4.1 \pm 0.4}{38 \pm 4}$ & $\frac{53 \pm 6}{30 \pm 4}$ & $\frac{3.45 \pm 0.23}{2.24 \pm 0.15}$ & 1.27 & 1.02 & 13.3 & $2.63 \pm 0.08$ & +0.77 \\
\hline \multicolumn{10}{|c|}{ Средняя тайга } & Типичная подзолистая почва \\
\hline $\mathrm{A} 0$ & $0-5$ & $\frac{45.6 \pm 1.5}{33.3 \pm 1.1}$ & $\frac{4.5 \pm 0.4}{39 \pm 4}$ & $\frac{48 \pm 10}{26 \pm 5}$ & $\frac{2.3 \pm 0.4}{1.42 \pm 0.26}$ & 1.17 & 0.78 & 23.4 & $2.22 \pm 0.07$ & +0.39 \\
\hline $\mathrm{A} 1 \mathrm{~A} 2 \mathrm{~h}$ & $5-7$ & $\frac{45.3 \pm 1.4}{33.0 \pm 1.1}$ & $\frac{4.5 \pm 0.4}{40 \pm 4}$ & $\frac{49 \pm 10}{27 \pm 5}$ & $\frac{1.21 \pm 0.22}{0.76 \pm 0.14}$ & 1.20 & 0.81 & 43.7 & $2.28 \pm 0.07$ & +0.42 \\
\hline $\mathrm{A} 2^{\prime}$ & $7-10$ & $\frac{44.9 \pm 1.4}{34.3 \pm 1.1}$ & $\frac{4.0 \pm 0.4}{36 \pm 3}$ & $\frac{50 \pm 10}{29 \pm 6}$ & $\frac{0.93 \pm 0.17}{0.61 \pm 0.11}$ & 1.06 & 0.84 & 56.3 & $2.18 \pm 0.07$ & +0.62 \\
\hline $\mathrm{A} 2 "$ & 18-35 & $\frac{45.2 \pm 1.4}{34.7 \pm 1.1}$ & $\frac{3.9 \pm 0.4}{36 \pm 3}$ & $\frac{50 \pm 10}{29 \pm 6}$ & $\frac{0.82 \pm 0.15}{0.54 \pm 0.10}$ & 1.04 & 0.83 & 64.3 & $2.15 \pm 0.06$ & +0.62 \\
\hline \multicolumn{11}{|c|}{ Торфянисто-подзолисто-глееватая почва } \\
\hline $\mathrm{O} 1$ & $0-8$ & $\frac{45.6 \pm 1.5}{33.9 \pm 1.1}$ & $\frac{4.2 \pm 0.4}{38 \pm 4}$ & $\frac{48 \pm 10}{27 \pm 5}$ & $\frac{2.4 \pm 0.4}{1.54 \pm 0.28}$ & 1.12 & 0.79 & 22.0 & $2.17 \pm 0.07$ & +0.45 \\
\hline A2hg & $12-20$ & $\frac{41.8 \pm 1.3}{33.3 \pm 1.1}$ & $\frac{3.6 \pm 0.3}{34 \pm 3}$ & $\frac{53 \pm 11}{32 \pm 6}$ & $\frac{1.7 \pm 0.3}{1.18 \pm 0.21}$ & 1.02 & 0.95 & 28.2 & $2.29 \pm 0.07$ & +0.88 \\
\hline$A 2 g^{\prime}$ & $20-28$ & $\frac{40.2 \pm 1.3}{31.0 \pm 1.0}$ & $\frac{4.0 \pm 0.4}{37 \pm 3}$ & $\frac{54 \pm 11}{31 \pm 6}$ & $\frac{1.36 \pm 0.24}{1.90 \pm 0.16}$ & 1.19 & 1.02 & 34.5 & $2.55 \pm 0.08$ & +0.85 \\
\hline A2g" & $28-37$ & $\frac{43.4 \pm 1.4}{30.8 \pm 1.0}$ & $\frac{4.9 \pm 0.5}{42 \pm 4}$ & $\frac{50 \pm 10}{26 \pm 5}$ & $\frac{2.1 \pm 0.4}{1.30 \pm 0.23}$ & 1.35 & 0.86 & 23.7 & $2.50 \pm 0.07$ & +0.36 \\
\hline \multicolumn{11}{|c|}{ Северная тайга } \\
\hline AO & $0-5$ & $\frac{49.1 \pm 1.6}{35.5 \pm 1.1}$ & $\frac{4.5 \pm 0.4}{39 \pm 4}$ & $\frac{44 \pm 9}{24 \pm 5}$ & $\frac{2.7 \pm 0.5}{1.7 \pm 0.3}$ & 1.10 & 0.67 & 21.3 & $2.00 \pm 0.06$ & +0.24 \\
\hline$A 2 g^{\prime}$ & $5-10$ & $\frac{49.8 \pm 1.6}{37.4 \pm 1.2}$ & $\frac{4.1 \pm 0.4}{37 \pm 3}$ & $\frac{44 \pm 9}{25 \pm 5}$ & $\frac{2.2 \pm 0.4}{1.44 \pm 0.26}$ & 0.98 & 0.66 & 26.0 & $1.86 \pm 0.06$ & +0.34 \\
\hline A2g" & $10-16$ & $\frac{48.5 \pm 1.6}{37.5 \pm 1.2}$ & $\frac{3.7 \pm 0.3}{35 \pm 3}$ & $\frac{45 \pm 9}{26 \pm 5}$ & $\frac{2.5 \pm 0.4}{1.63 \pm 0.29}$ & 0.92 & 0.70 & 23.0 & $1.86 \pm 0.06$ & +0.48 \\
\hline A2B & $16-35$ & $\frac{47.2 \pm 1.5}{34.5 \pm 1.1}$ & $\frac{4.4 \pm 0.4}{39 \pm 4}$ & $\frac{46 \pm 9}{25 \pm 5}$ & $\frac{2.6 \pm 0.5}{1.62 \pm 0.29}$ & 1.12 & 0.73 & 21.4 & $2.10 \pm 0.06$ & +0.34 \\
\hline \multicolumn{11}{|c|}{ Торфянисто-подзолисто-глееватая почва } \\
\hline $\mathrm{O} 1$ & $0-10$ & $\frac{43.9 \pm 1.4}{33.6 \pm 1.1}$ & $\frac{3.9 \pm 0.4}{36 \pm 3}$ & $\frac{49 \pm 10}{28 \pm 6}$ & $\frac{2.7 \pm 0.5}{1.8 \pm 0.3}$ & 1.08 & 0.84 & 19.1 & $2.21 \pm 0.07$ & +0.61 \\
\hline $\mathrm{O} 2$ & $10-12$ & $\frac{41.3 \pm 1.3}{32.1 \pm 1.0}$ & $\frac{3.8 \pm 0.4}{36 \pm 3}$ & $\frac{53 \pm 11}{31 \pm 6}$ & $\frac{1.58 \pm 0.28}{1.05 \pm 0.19}$ & 1.11 & 0.97 & 30.5 & $2.41 \pm 0.07$ & +0.82 \\
\hline A2hg & $12-15$ & $\frac{33.0 \pm 1.1}{27.8 \pm 0.9}$ & $\frac{3.16 \pm 0.29}{32 \pm 3}$ & $\frac{63 \pm 13}{40 \pm 8}$ & $\frac{1.03 \pm 0.19}{0.74 \pm 0.13}$ & 1.15 & 1.42 & 37.4 & $3.06 \pm 0.09$ & +1.70 \\
\hline $\mathrm{A} 2 \mathrm{~g}$ & $15-20$ & $\frac{38.8 \pm 1.2}{32.5 \pm 1.0}$ & $\frac{3.05 \pm 0.28}{30.7 \pm 2.9}$ & $\frac{57 \pm 12}{36 \pm 7}$ & $\frac{1.27 \pm 0.23}{0.91 \pm 0.16}$ & 0.94 & 1.10 & 35.7 & $2.42 \pm 0.07$ & +1.26 \\
\hline $\mathrm{A} 2 \mathrm{Bg}$ & $20-25$ & $\frac{34.7 \pm 1.1}{29.7 \pm 1.0}$ & $\frac{2.94 \pm 0.27}{30.2 \pm 2.8}$ & $\frac{61 \pm 13}{39 \pm 8}$ & $\frac{1.25 \pm 0.23}{0.92 \pm 0.17}$ & 1.02 & 1.32 & 32.3 & $2.78 \pm 0.08$ & +1.62 \\
\hline $\mathrm{A} 2 \mathrm{Bg}$ & $35-40$ & $\frac{41.9 \pm 1.3}{34.2 \pm 1.2}$ & $\frac{3.3 \pm 0.3}{32 \pm 3}$ & $\frac{53 \pm 11}{32 \pm 6}$ & $\frac{2.1 \pm 0.4}{1.48 \pm 0.27}$ & 0.94 & 0.94 & 23.1 & $2.20 \pm 0.07$ & +0.95 \\
\hline \multicolumn{11}{|c|}{ Южная тундра } \\
\hline AO & $0-5$ & $\frac{49.1 \pm 1.6}{35.8 \pm 1.1}$ & $\frac{4.4 \pm 0.4}{38 \pm 4}$ & $\frac{44 \pm 9}{24 \pm 5}$ & $\frac{2.4 \pm 0.4}{1.47 \pm 0.27}$ & 1.07 & 0.68 & 24.3 & $1.98 \pm 0.06$ & +0.28 \\
\hline AOAh & $5-10$ & $\frac{38.1 \pm 1.2}{30.4 \pm 1.0}$ & $\frac{3.6 \pm 0.3}{35 \pm 3}$ & $\frac{56 \pm 12}{34 \pm 7}$ & $\frac{1.9 \pm 0.3}{1.29 \pm 0.23}$ & 1.14 & 1.11 & 23.6 & $2.63 \pm 0.08$ & +1.09 \\
\hline
\end{tabular}


Окончание табл. 3

\begin{tabular}{|c|c|c|c|c|c|c|c|c|c|c|}
\hline \multirow[t]{2}{*}{ Горизонт } & \multirow{2}{*}{$\begin{array}{c}\text { Глубина, } \\
\text { см }\end{array}$} & \multicolumn{4}{|c|}{ Содержание, \% } & \multicolumn{3}{|c|}{$\begin{array}{c}\text { Атомные } \\
\text { отношения }\end{array}$} & \multirow[t]{2}{*}{$(\mathrm{H} / \mathrm{C})_{\text {ucn }}$} & \multirow{2}{*}{$\begin{array}{c}\text { Степень } \\
\text { окисленности } \\
(\omega)\end{array}$} \\
\hline & & $\mathrm{C}$ & $\mathrm{H}$ & $\mathrm{O}$ & $\mathrm{N}$ & $\mathrm{H} / \mathrm{C}$ & $\mathrm{O} / \mathrm{C}$ & $\mathrm{C} / \mathrm{N}$ & & \\
\hline G & $10-28$ & $\frac{37.4 \pm 1.2}{28.2 \pm 0.9}$ & $\frac{4.3 \pm 0.4}{39 \pm 4}$ & $\frac{56 \pm 11}{32 \pm 6}$ & $\frac{2.4 \pm 0.4}{1.52 \pm 0.27}$ & 1.37 & 1.12 & 18.6 & $2.88 \pm 0.09$ & +0.87 \\
\hline \multicolumn{11}{|c|}{ Торфянисто-тундровая глеевая почва } \\
\hline $\mathrm{O}$ & $0-14$ & $\frac{46.3 \pm 1.5}{33.8 \pm 1.1}$ & $\frac{4.4 \pm 0.4}{39 \pm 4}$ & $\frac{48 \pm 10}{26 \pm 5}$ & $\frac{1.8 \pm 0.3}{1.10 \pm 0.20}$ & 1.15 & 0.77 & 30.7 & $2.19 \pm 0.07$ & +0.39 \\
\hline G & $17-25$ & $\frac{38.3 \pm 1.2}{28.5 \pm 0.9}$ & $\frac{4.4 \pm 0.4}{39 \pm 4}$ & $\frac{55 \pm 11}{31 \pm 6}$ & $\frac{2.1 \pm 0.4}{1.36 \pm 0.24}$ & 1.38 & 1.08 & 21.0 & $2.82 \pm 0.08$ & +0.78 \\
\hline \multicolumn{11}{|c|}{ Торфяно-тундровая глеевая почва } \\
\hline $\mathrm{O}$ & $0-26$ & $\frac{45.9 \pm 1.5}{34.0 \pm 1.0}$ & $\frac{4.3 \pm 0.4}{38 \pm 4}$ & $\frac{48 \pm 10}{26 \pm 5}$ & $\frac{2.2 \pm 0.4}{1.42 \pm 0.26}$ & 1.12 & 0.78 & 23.9 & $2.16 \pm 0.06$ & +0.44 \\
\hline Gf & $28-40$ & $\frac{41.0 \pm 1.3}{29.0 \pm 1.0}$ & $\frac{5.0 \pm 0.5}{42 \pm 4}$ & $\frac{52 \pm 11}{28 \pm 6}$ & $\frac{1.9 \pm 0.3}{1.16 \pm 0.21}$ & 1.45 & 0.95 & 25.1 & $2.73 \pm 0.08$ & +0.46 \\
\hline
\end{tabular}

Примечание: * $(\mathrm{H} / \mathrm{C})_{\text {исп }}=(\mathrm{H} / \mathrm{C})+2 \times(\mathrm{O} / \mathrm{C}) \times 0.67$ (Орлов, 1985); над чертой - массовая доля, под чертой - мольная доля $(x)$; все расчеты приведены на абсолютно сухие и обеззоленные препараты.

провождающаяся декарбоксилированием и уменьшением доли углеводных и аминокислотных фрагментов в структуре ГК, что приводит к уменьшению величин соотношения $(\mathrm{H} / \mathrm{C})_{\text {исп }}$. Увеличение степени гидроморфизма в таежных почвах сопровождается увеличением значений $(\mathrm{H} / \mathrm{C})_{\text {исп }}$, что обусловлено более низкой микробиологической активностью болотно-подзолистых почв (Хабибуллина, 2014), которая способствует лучшей сохранности углеводных и аминокислотных фрагментов в структуре ГК. Анализ әлементного состава ГК тундровых почв выявил уменьшение по профилю значений $(\mathrm{H} / \mathrm{C})_{\text {исп }}$ во всех почвах, что свидетельствует об увеличении доли ароматических фрагментов в структуре ГК минеральных горизонтов. Статистически достоверных различий в значениях $(\mathrm{H} / \mathrm{C})_{\text {исп }} \Gamma К$ тундровых почв разной степени гидроморфизма не установлено.
Расчет степени окисленности показал, что практически все исследованные ГК слабо восстановлены ( $\omega$ от -0.91 до -0.02). Исключение составили ГК дерново-подзолистых почв, величина степени окисленности достигает +0.17. ФК представляют собой более окисленные соединения, и показатель их степени окисленности варьирует от +0.24 до +2.09 . Результаты исследований показали, что наиболее окисленными являются ГВ минеральных горизонтов изучаемых почв, что обусловливает миграцию окисленных (и, как следствие, более водорастворимых) $\Phi$ К вниз по профилю. Высокая восстановленность препаратов ГК и ФК органогенных горизонтов определяется постоянным поступлением свежих органических остатков и их слабой гумификацией в специфических биоклиматических условиях Севера.

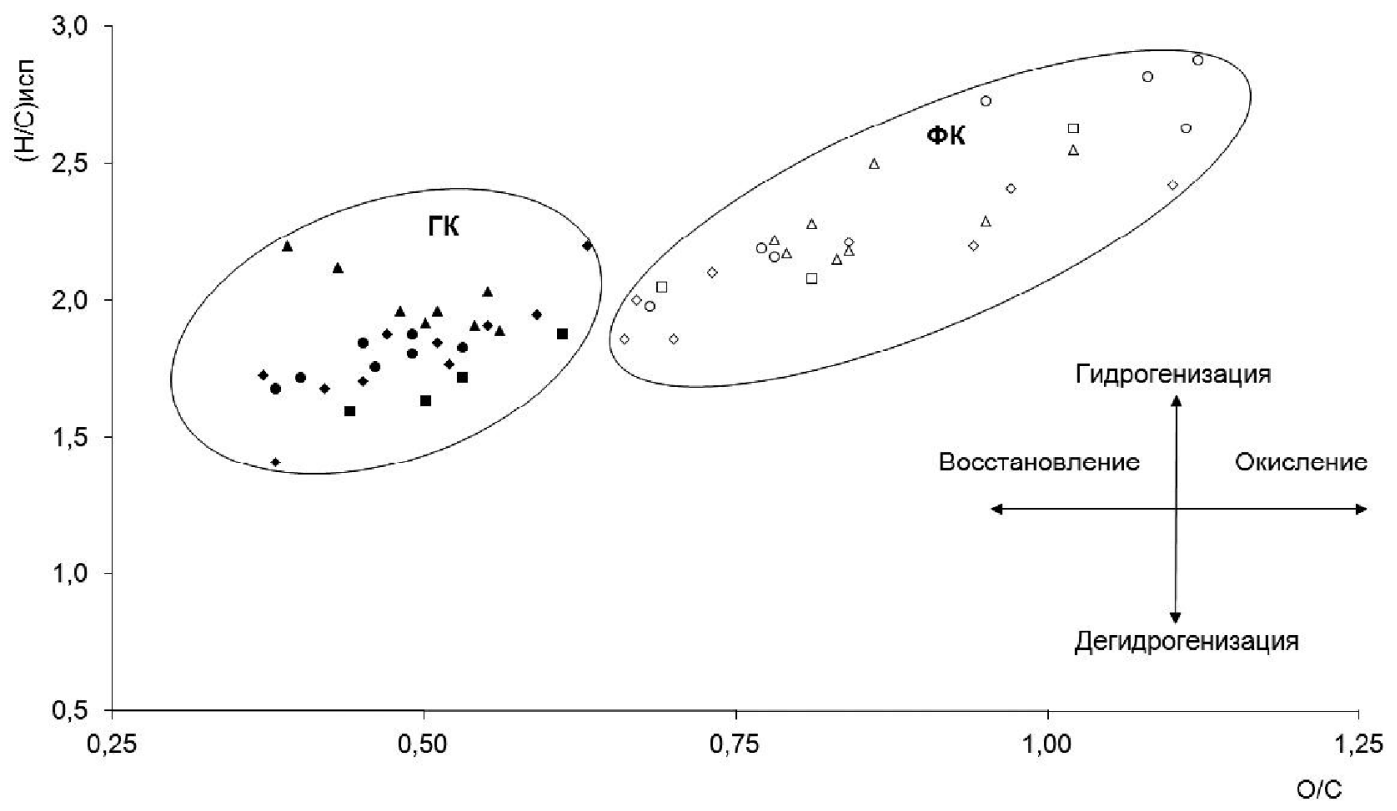

Рис. 3. Атомные соотношения элементов в препаратах гуминовых и фульвокислот почв южной (ГКп, ФК $\square$ ), средней (ГКА, ФК $\triangle$ ), северной тайги (ГК 
Один из наиболее широко распространенных методов, применяемых для численного описания строения гумусовых кислот с целью выявления закономерностей их образования и трансформации, является построение диаграмм Д. ван Кревелена. Способ основывается на графическом представлении данных в координатах $\mathrm{H} / \mathrm{C}_{\text {исп }}-\mathrm{O} / \mathrm{C}$ и служит удобным приемом для демонстрации вклада процессов окисления и конденсации в изменение элементного состава препаратов (Kleinhempel, 1970). На основании диаграммы Д. ван Кревелена (рис. 3) установлено, что процесс гумификации растительных остатков вызывает сниже-

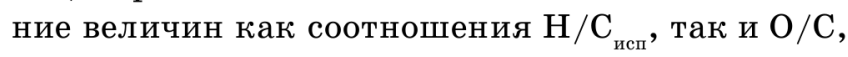
т.е. сопровождается увеличением доли ароматических структур в молекулах гумусовых кислот. Графико-статистический анализ демонстрирует более высокую окисленность и низкую обуглероженность ФК по сравнению с ГК, что указывает на значительную замещенность ароматических колец и развитие боковых алифатических цепей. Полученные нами результаты в целом согласуются с известными данными как для тундровых почв Аляски (Characterization..., 2001), так и для подзолистых и болотно-подзолистых почв центра Русской равнины (Humic..., 1997; Кечайкина, 2011).

\section{Заключение}

Впервые получен массив данных по элементному составу препаратов гумусовых веществ таежных и тундровых почв разного генезиса и проведен сравнительный анализ этих результатов на европейском северо-востоке России. Полученные данные в совокупности со структурно-функциональными параметрами ГВ позволили выявить закономерности гумусообразования почв, обусловленные низкой скоростью разложения растительных остатков, включением относительно больших количеств лабильных углеводных, аминокислотных и метоксильных групп в структуру ГВ. Показано, что в профильном распределении азота в препаратах ГК и ФК отмечается тенденция к его снижению. Гуминовые и фульвокислоты дерново-подзолистых почв в большей степени обогащены азотом по сравнению с другими исследованными почвами.

Установлено, что усиление степени гидроморфизма в таежных почвах сопровождается увеличением значений $(\mathrm{H} / \mathrm{C})_{\text {исп }}$, чо определяется более низкой микробиологической активностью болотно-подзолистых почв, которая способствует лучшей сохранности углеводных и аминокислотных фрагментов в структуре ГК. Анализ элементного состава ГК тундровых почв выявил уменьшение по профилю значений $(\mathrm{H} / \mathrm{C})_{\text {исп }}$ во всех потвах, тто свидетельствует об увелитении доли ароматических фрагментов в структуре ГК минеральных горизонтов. Статистически достовер- ных различий в значениях $(\mathrm{H} / \mathrm{C})_{\text {исп }} \Gamma$ тундровых почв разной степени гидроморфизма не установлено.

Графико-статистический анализ демонстрирует более высокую окисленность и низкую обуглероженность $Ф К$ по сравнению с ГК, что указывает на значительную замещенность ароматических колец и развитие боковых алифатических цепей.

Работа выполнена в ралках госзадания ( № Гр 115020910065) и Программы УрО РАН № 15-24-5 (№ zос. рег. 115082010009 ).

\section{ЛИТЕРАТУРА}

Абакумов, Е. В. Элементный состав и структурные особенности гуминовых веществ молодых подзолов, формирующихся на отвалах песчаного карьера / Е. В. Абакумов // Почвоведение. - 2009. № 6. - С. 666-673.

Атлас по климату и гидрологии Республики Коми. - М. : Дрофа; ДиК, 1997. - 116 с.

Атлас почв Республики Коми / И. В. Забоева, А. И. Таскаев, Г. В. Добровольский, В. А. Безносиков, Г. Я. Елькина, Д. А. Каверин, Е. Д. Лодыгин, Н. Г. Оберман, Е. М. Лаптева, Г. В. Русанова, Е. Д. Никитин, И. Б. Арчегова, Е. В. ЗЖангуров, А. Н. Панюков, А. В. Пастухов, И. А. Лиханова, Г. А. Симонов, Г. Г. Мажитова, Г. М. Втюрин, В. Г. Казаков, В. В. Елсаков, Л. Н. Рыбин, В. В. Мокиев, Б. М. Кондратенок ; ред. Г. В. Добровольский, А. И. Таскаев, И. В. Забоева. - Сыктывкар, 2010. - 356 с.

Безносиков, В. А. Фракционно-групповой состав гумуса криогенных поверхностно-глеевых и гидроморфных почв Большеземельской тундры / В. А. Безносиков, Е. Д. Лодыгин // Вестник Санкт-Петербургского университета. Серия 3: Биология. 2012. - Вып. 1. - С. 107-120.

ГОСТ 11306-83. Торф и продукты его переработки. Методы определения зольности. Утвержден Постановлением Государственного комитета СССР по стандартам от 21.09.1983 № 4465 (Измененная редакция. Изм. № 1). - М. : Изд-во стандартов, 1995. - 7 c.

ГОСТ 17.4.3.01-83. Охрана природы. Почвы. Общие требования к отбору проб. Утвержден Постановлением Государственного комитета ССCP по стандартам от 21.12.1983 № 6393. - М. : ФГУП Стандартинформ, 2008. - 3 с.

ГОСТ 17.4.4.02-84. Охрана природы. Методы отбора и подготовки проб для химического, бактериологического и гельминтологического анализа. Утвержден Постановлением Государственного комитета СССР по стандартам от 19.12.1984 № 4731. М. : ФГУП Стандартинформ, 2008. - 7 с.

Дергачева, М. И. Гумусовые вещества как источник информации о природной среде формирования / М. И. Дергачева // Изв. аграрной науки. 2011. - Т. 9. - № 2. - С. 57-61.

Завьялова, Н. Е. Влияние приемов землепользования на трансформацию гуминовых кислот дерново-подзолистой тяжелосуглинистой почвы Предуралья / Н. Е. Завьялова, В. А. Кончиц // Почвоведение. - 2011. - № 1. - С. 103-110. 
Кечайкина, И. О. Постагрогенная трансформация органического вещества дерново-подзолистых почв / И. О. Кечайкина, А. Г. Рюмин, С. Н. Чуков // Почвоведение. - 2011. - № 10. - С. 1-14.

Кондратенок, Б. М. Методика измерений содержания водорода в твердых объектах методом газовой хроматографии на элементном анализаторе EA 1110 (CHNS-O) : свидетельство об аттестации методики измерений / Б. М. Кондратенок, Е. В. Ванчикова, А. Г. Естафьева ; Федеральное государственное бюджетное учреждение науки Институт биологии Коми научного центра Уральского отделения Российской академии наук. - № 88-17641-116-2011, дата выдачи свидетельства 2011, ФР.1.31.2011. 10016.

Максимова, Е. Ю. Зольный состав верхних горизонтов и основные биологические параметры почв тольяттинского островного бора и их изменение в результате действия лесных пожаров / Е. Ю. Максимова, Е. В. Абакумов // Вестник Санкт-Петербургского университета. Серия 3: Биология. 2014. - Вып. 1. - С. 132-143.

Методика выполнения измерений содержания углерода и азота в твердых объектах методом газовой хроматографии на элементном анализаторе ЕА 1110 (CHNS-O) : свидетельство об аттестации методики измерений ; Федеральное государственное бюджетное учреждение науки Институт биологии Коми научного центра Уральского отделения Российской академии наук. - № 88-17641-94-2009, дата выдачи свидетельства 2009, ФР.1.31.2014.17663, с изменением № 1 от 16.01.2014.

Мотузова, Г. В. Сравнительная характеристика гуминовых кислот пахотных почв таежной, степной и полупустынной зон / Г. В. Мотузова, Х. М. Дерхам, А. А. Степанов // Почвоведение. - 2012. № 11. - C. 1171-1180.

Некрасова, О. А. Элементный состав гуминовых кислот южнотаежных почв Среднего Урала и прилегающих территорий / О. А. Некрасова // Вестник КрасГАУ. - 2013. - № 3. - С. 23-28.

Орлов, Д. С. Гумусовые кислоты почв / Д. С. Орлов. - М. : Изд-во МГУ, 1974. - 335 с.

Путеводитель научной почвенной экскурсии / Лесная зона (сезонно-промерзающие почвы) / Г. М.
Втюрин, И. В. Забоева, В. А. Безносиков, Г. А. Симонов, В. Г. Казаков, Г. Я. Елькина, Е. М. Лаптева, Е. Д. Лодыгин, Ф. М. Хабибуллина, Е. В. Шамрикова. - Сыктывкар : Институт биологии Коми НЦ УрО РАН, 2002. - 100 c.

Трансформация гуминовых кислот погребенных почв / Л. В. Багаутдинова, А. Г. Рюмин, И. О. Кечайкина, С. Н. Чуков // Вестник Санкт-Петербургского университета. Серия 3: Биология. - 2012. Вып. 2. - С. 92-108.

Хабибуллина, Ф. М. Микромицеты подзолистых и болотно-подзолистых почв в подзоне средней тайги на северо-востоке европейской части России / Ф. М. Хабибуллина, Е. Г. Кузнецова, И. З. Васенева // Почвоведение. - 2014. - № 10. - С. 12281234. - DOI: 10.7868/S0032180X14100049.

Элементный состав гуминовых кислот целинных черноземов разных условий формирования / М. И. Дергачева, О. А. Некрасова, Д. И. Васильева, В. П. Фадеева // Вестник ОГУ. - 2012. - № 10 (146). C. 87-93.

Characterization of soil organic matter fractions of tundra soils in arctic Alaska by Carbon-13 nuclear magnetic resonance spectroscopy / X. Y. Dai, C. L. Ping, R. Candler, L. Haumaier, W. Zech // Soil Sci. Soc. Am. J. - 2001. - V. 65. - P. 87-93.

Graham, D. J. Graphical representation of particle shape using triangular diagrams: an Excel spreadsheet method / D. J. Graham, N. G. Midgley // Earth Surface Processes and Landforms. - 2000. - V. 25. № 13. - P. 1473-1477.

Humic substances from podzols under Oak Forest and a Cleared Forest Site I. Isolation and Characterization / A. J. Simpson, B. E. Watt, C. L. Graham, M. H. B. Hayes // Humic Substances, Peats and Sludges. Health and Environmental Aspects / eds. M. H. B. Hayes, W. S. Wilson. - Woodhead Publ. Ltd., 1997. - P. 73-82. - DOI: 10.1016/B978-1-85573805-8.50010-0.

Kleinhempel D. Ein Beitrag zur Theorie des Huminstoffezustondes // Albrecht-Thaer-Archiv. 1970. - N 14(1). - P. 3-14.

World reference base for soil resources: A framework for international classification, correlation and communication. - Rome : FAO, 2006. - 128 p.

\title{
THE STUDY OF THE ELEMENTAL COMPOSITION OF HUMIC AND FULVIC ACIDS OF SOILS OF TAIGA AND TUNDRA LANDSCAPES
}

\author{
E.D. Lodygin, V.A. Beznosikov, R.S. Vasilevich \\ Institute of Biology of Komi Scientific Centre of the Ural Branch of the Russian Academy of Sciences, Syktyvkar
}

Abstract. A systematic study of the elemental composition of preparations of humic (HAs) and fulvic acids (FAs) of soils of different climatic zones of the Republic of Komi. HAs of taiga soils are more enriched in nitrogen and FAs - oxygen compared with tundra soils. The structure of HAs and FAs of tundra soils is characterized by the presence of a developed part of the aliphatic macromolecules and low degree of aromaticity.

Key words: soil, humic and fulvic acids, elemental composition, taiga, tundra 